\title{
Isolation and Characterization of an Aluminum-resistant Mutant in Rice
}

\author{
Shuo Liu, Huiling Gao, Xiaoyan Wu, Qiu Fang, Lan Chen, Fang-Jie Zhao and Chao-Feng Huang* (i)
}

\begin{abstract}
Background: Aluminum (Al) toxicity represents a major constraint for crop production on acid soils. Rice is a high Al-resistant plant species among small-grain cereals, but its molecular mechanisms of Al resistance are not fully understood. We adopted a forward genetic screen strategy to uncover the Al-resistance mechanisms in rice. In this study, we screened an ethylmethylsulfone (EMS)-mutagenized library to isolate and characterize mutants with altered sensitivity to $\mathrm{Al}$ in rice.

Results: Treatment of an Al-intolerant indica variety Kasalath with $20 \mu \mathrm{M} \mathrm{Al}$ induced root swelling. This phenotype could be suppressed by the addition of aminoethoxyvinylglycine (AVG, an ethylene synthesis inhibitor), suggesting that increased production of ethylene is responsible for the root swelling under Al stress. By utilizing the root swelling as an indicator, we developed a highly effective method to screen Al-sensitive or -resistant mutants in rice. Through screening of $\sim 5000 \mathrm{M} 2$ lines, we identified $10 \mathrm{Al}$-sensitive mutants and one Al-resistant mutant ral1 (resistance to aluminum 1). rall mutant showed short root phenotype under normal growth condition, which was attributed to reduced cell elongation in the mutant. A dose-response experiment revealed that ral1 mutant was more resistant to Al than wild-type (WT) at all Al concentrations tested. The mutant was also more resistant to Al when grown in an acid soil. The mutant accumulated much lower Al in the root tips $(0-1 \mathrm{~cm})$ than WT. The mutant contained less Al in the cell wall of root tips than WT, whereas Al concentration in the cell sap was similar between WT and the mutant. In addition to Al, the mutant was also more resistant to Cd than WT. Quantitative RT-PCR analysis showed that the expression levels of known Al-resistance genes were not increased in the mutant compared to WT. Genetic analysis indicated that the Al-resistance phenotype in ral1 mutant was controlled by a single recessive gene mapped on the long arm of chromosome 6.

Conclusions: We have developed a highly efficient method for the screening of rice mutants with altered $\mathrm{Al}$ sensitivity. We identified a novel mutant ral1 resistant to Al by this screening. The increased resistance of ral1 to Al toxicity is caused by the reduced Al binding to the cell wall of root tips and the responsible gene is mapped on the long arm of chromosome 6 .
\end{abstract}

Keywords: Aluminum toxicity, Aluminum resistance, Mapping, Mutant, Rice, Screening

\section{Background}

Aluminum ( $\mathrm{Al})$ is the third most abundant element after oxygen and silicon in the soil and comprises about $7 \%$ of the earth's crust. Most Al exists as insoluble aluminosilicates or oxides, which are non-toxic to plants grown in mildly acidic or neutral soils. However, in acid soils with a $\mathrm{pH}$ of 5.5 or lower, $\mathrm{Al}$ is solubilized and released into the soil as $\mathrm{Al}^{3+}$ which will inhibit plant growth. As

\footnotetext{
* Correspondence: chaofeng.huang@njau.edu.cn

State Key Laboratory of Crop Genetics and Germplasm Enhancement, College of Resources and Environmental Science, Nanjing Agricultural University, Nanjing 210095, China
}

a consequence, $\mathrm{Al}$ toxicity is one of the most severe global problems of acid soils especially since these soils comprise approximately $30 \%$ of the world's arable land (von Uexkull and Mutert 1995). To cope with Al toxicity on acid soils, some plant species have evolved Alresistance mechanisms.

Numerous studies indicate that organic acid anions play critical roles in the detoxification of $\mathrm{Al}$ (Ma 2000; Ryan et al. 2001; Ma et al. 2001). In response to $\mathrm{Al}$, plants secrete organic acids such as malate, citrate and oxalate to chelate $\mathrm{Al}$ and thereby alleviate $\mathrm{Al}$ toxicity. $\mathrm{A}$ number of plant species are documented to secrete 
different organic acids to detoxify Al. For instance, wheat (Triticum aestivum), Arabidopsis thaliana and oilseed rape (Brassica napus) release malate for $\mathrm{Al}$ detoxification (Delhaize et al. 1993; Ligaba et al. 2006; Hoekenga et al. 2003), whereas snapbean (Phaseolus vulgaris), rice bean (Vigna umbellata), maize (Zea mays), and soybean (Glycine max) secrete citrate to detoxify $\mathrm{Al}$ (Miyasaka et al. 1991; Pellet et al. 1995; Yang et al. 2000; Liu et al. 2013; Yang et al. 2006). Oxalate is exuded from roots of buckwheat, tomato and spinach (Spinacia oleracea) under Al stress (Ma et al. 1997; Zheng et al. 1998; Yang et al. 2005; Yang et al. 2011). Recently, genes responsible for the Al-activated secretion of malate and citrate have been identified in plants (Furukawa et al. 2007; Magalhaes et al. 2007; Sasaki et al. 2004), but genes required for oxalate release are still unknown.

In addition to organic acid-based mechanisms of $\mathrm{Al}$ detoxification, recent molecular genetic studies on the model plants rice and Arabidopsis have revealed some novel Al-resistance mechanisms. Through a forward genetic screen, two research groups identified C2H2type zinc-finger transcription factors STOP1 and ART1 involved in $\mathrm{Al}$ resistance in Arabidopsis thaliana and rice, respectively (Yamaji et al. 2009; Iuchi et al. 2007). STOP1/ART1 regulates the downstream Al-resistance genes to confer $\mathrm{Al}$ resistance. STAR1 and STAR2/ALS3 that encode a nucleotide-binding domain and a transmembrane domain of an ABC (ATP-binding cassette) transporter, respectively, interact with each other to form a complex and then transport UDP-glucose for the cell wall modification to detoxify Al (Larsen et al. 2005; Huang et al. 2009a; Huang et al. 2010). ALS1 encoding a half-size $\mathrm{ABC}$ transporter is involved in the sequestration of $\mathrm{Al}$ into the vacuoles (Huang et al. 2012a; Larsen et al. 2007), which suggests that in addition to $\mathrm{Al} \mathrm{accu-}$ mulator species, normal plant species also possess internal $\mathrm{Al}$ detoxification mechanisms. By examining the function of the downstream genes of ART1, Ma's group also identified several additional Al-resistance genes involved in various processes of $\mathrm{Al}$ detoxification in rice (Xia et al. 2010; Chen et al. 2012; Yokosho et al. 2011; Xia et al. 2013). More recently, Arenhart et al. (2013) reported that a transcription factor ASR5 (abscisic acid, stress and ripening) is required for $\mathrm{Al}$ detoxification in rice. They further demonstrated that ASR5 regulates $\mathrm{Al}$ resistance through direct binding to the promoters of target genes including the key Al-resistance gene STAR1 (Arenhart et al. 2013; Arenhart et al. 2014).

Japonica rice is the most Al-resistant plant species among small-grain cereal crops. Compared to japonica cultivars, indica cultivars are less resistant to $\mathrm{Al}$. A number of quantitative trait loci (QTLs) responsible for the differential Al resistance between japonica and indica varieties have been identified (Xue et al. 2007; Nguyen et al. 2003; Ma et al. 2002; Nguyen et al. 2002; Nguyen et al. 2001; Wu et al. 2000). However, due to the minor effect of each QTL on the Al resistance, cloning of the responsible genes by a map-based cloning approach is greatly hampered. Alternatively, mutant screening followed by map-based cloning of the responsible gene is an effective strategy to identify new genes and discover novel mechanisms in plant species with known genome sequence including rice. Through this strategy, several rice mutants with increased sensitivity to $\mathrm{Al}$ were isolated and the responsible genes were cloned and characterized (Yamaji et al. 2009; Ma et al. 2005; Huang et al. 2009b; Huang et al. 2009a; Huang et al. 2012b). Previously, the method used to screen Al-sensitive mutants was based on the measurement of root length of each plant before and after $\mathrm{Al}$ treatment. This screening method is time-consuming and laborintensive ( $\mathrm{Ma}$ et al. 2005). In this study, we developed an easy and efficient screening method for isolation of Al-sensitive or Al-resistant mutants to further examine the Al-resistance mechanisms in rice. We chose an indica variety for mutagenesis and mutant screening because this variety showed less resistant to $\mathrm{Al}$ and Al-induced root swelling phenotype, which allows us to screen both Al-sensitive and Al-resistant mutants efficiently. Through this screen, we identified a rice mutant with increased resistance to Al toxicity. The mutant was characterized physiologically and genetically.

\section{Results}

\section{Development of an Efficient Screening Method for} Isolation of Rice Mutants with Altered Al Sensitivity

Using the laborious root length method, Ma et al. (2005) and Huang et al. (2009b) screened less than 2000 rice lines, which was far from saturation, implying that more Al-sensitive or Al-resitant mutants await to be screened. We found that $\mathrm{Al}$ treatment was able to induce root swelling in all 8 Al-intolerant indica cultivars including Kasalath used in this study (Fig. 1a), which could be used as a marker to indicate the root length before $\mathrm{Al}$ treatment. Unlike the indica cultivars, Al-resistant japonica cultivars did not show the Al-induced root swelling phenotype at all $\mathrm{Al}$ concentrations tested (Fig. 1b). These results demonstrated that Al toxicity can induce root swelling in Al-intolerant cultivars (indica cultivars), but not in Al-resistant cultivars (japonica cultivars). A dose-response experiment revealed that the optimal Al concentration for the induction of root swelling in the Kasalath cultivar is $20 \mu \mathrm{M} \mathrm{Al}$ (Fig. 1c), which inhibited root elongation of Kasalath by $54 \%$. Increased biosynthesis of the plant hormone ethylene under $\mathrm{Al}$ stress is suggested to be responsible for the Al-induced root swelling phenotype in soybean 

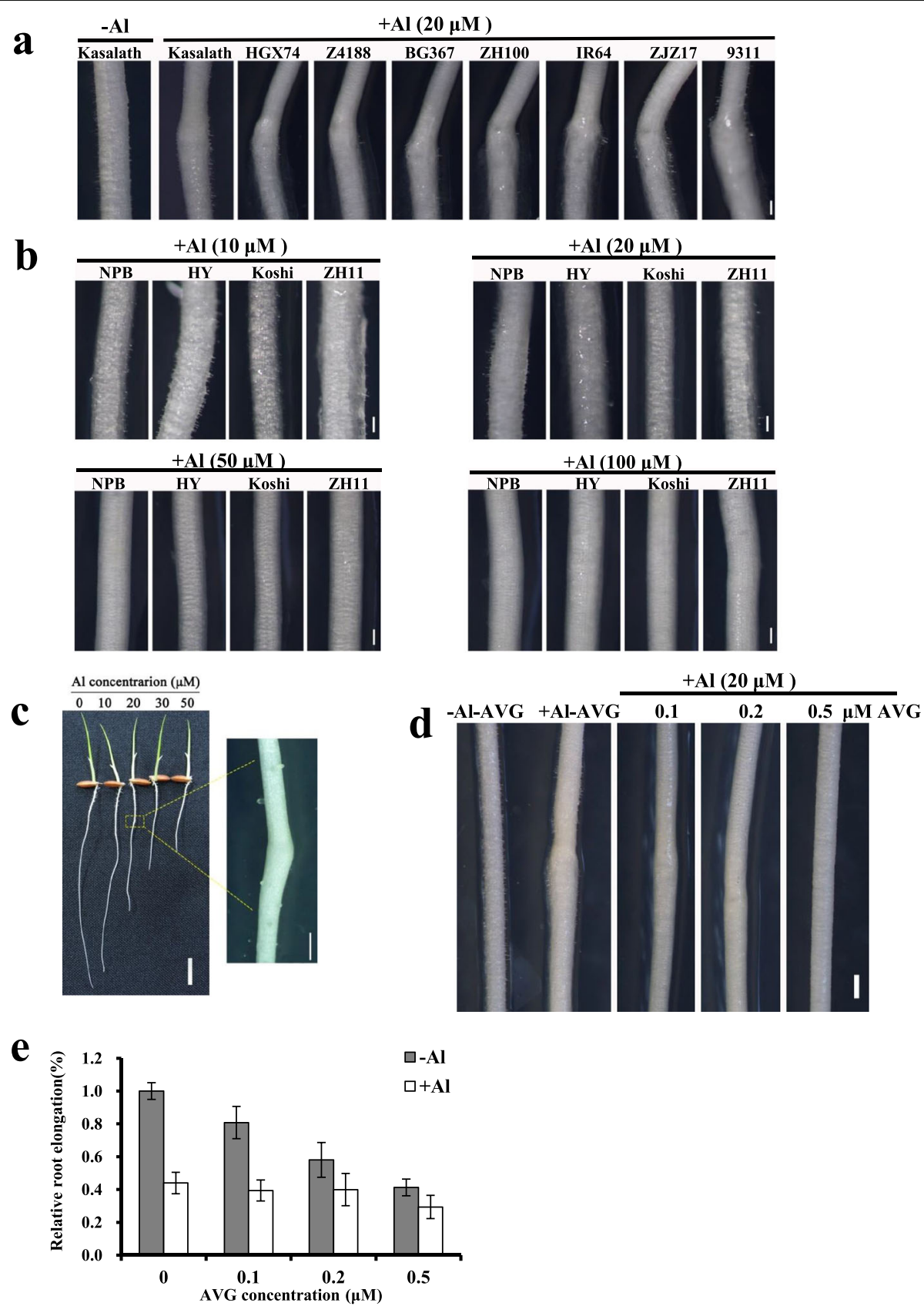

Fig. 1 Effect of Al and aminoethoxyvinylglycine (AVG) on root swelling and root elongation. a Root swelling phenotype of indica cultivars under Al stress. Roots were exposed to $-\mathrm{Al}$ or $+\mathrm{Al}(20 \mu \mathrm{M})$ condition for $24 \mathrm{~h}$. Scale bar $=500 \mu \mathrm{m}$. b Al stress did not induce root swelling in japonica cultivars. Roots were exposed to a series of Al concentrations (10, 20, 50 or $100 \mu \mathrm{M})$ for $24 \mathrm{~h}$. Scale bar $=500 \mu \mathrm{m}$. c Root swelling occurrence of Kasalath cultivar under different Al concentrations. Roots were exposed to a series of Al concentrations $(0,10,20,30$, or $50 \mu \mathrm{M})$ for $24 \mathrm{~h}$. Scale bar in left and right panel is $1 \mathrm{~cm}$ and $500 \mu \mathrm{m}$, respectively. d, e Effect of AVG on Al-induced root swelling (d) and root elongation (e). Roots were treated with $0,0.1,0.2$ or $0.5 \mu \mathrm{M}$ AVG in combination with 0 or $20 \mu \mathrm{M}$ Al for $24 \mathrm{~h}$. Scale bar $=500 \mu \mathrm{m}$

(Kopittke et al. 2015). To investigate whether the Alinduced root swelling in the rice cultivar Kasalath was caused by the ethylene, we used an ethylene synthesis inhibitor, aminoethoxyvinylglycine (AVG), to reduce the ethylene production in $\mathrm{Al}$-treated roots. Results showed that the addition of AVG could attenuate the root swelling induced by $\mathrm{Al}$ toxicity, and increase of AVG concentration to $0.5 \mu \mathrm{M}$ was able to fully suppress the root swelling phenotype (Fig. 1d). Although AVG treatment alone inhibited root elongation in a concentration-dependent manner, supply of both Al and AVG did not show additive 
effect on the inhibition of root elongation, suggesting that AVG could ameliorate the Al toxicity to some extent (Fig. 1e). Together, these results suggest that $\mathrm{Al}$-induced root swelling in Kasalath cultivar might be caused by increased ethylene production.

The root swelling marker allowed us to compare the root elongation difference after exposure to Al through visual inspection without the need to measure the root length. We generated a mutant library with Kasalath genetic background through ethylmethylsulfone (EMS) mutagenesis, and screened mutants with altered $\mathrm{Al}$ sensitivity by treating $\mathrm{M}_{2}$ seedlings with $20 \mu \mathrm{M} \mathrm{Al}$ for 3 days. Root elongation from the swelling marker was assessed visually. Seedlings with root elongation either less than half or more than two folds of the normal length were selected as $\mathrm{Al}$-sensitive or $\mathrm{Al}$-resistant candidate mutants, respectively. We also retained mutants without the occurrence of root swelling after exposure to Al. By this method, we easily screened $\sim 5000$ M2 lines and obtained 243 candidate mutants. In the second screening, $M_{3}$ generation of each candidate mutant was evaluated for their resistance to $\mathrm{Al}$ based on relative root elongation (RRE). As a result, 10 Al-sensitive and one Al-resistant mutants were confirmed. In the present study, the Al-resistant mutant ral1 (resistance to aluminum 1) was selected for further characterization.

\section{Response of ral1 Mutant to Al and Other Metals}

The ral1 mutant did not exhibit the typical root swelling phenotype in response to $\mathrm{Al}$ treatment (Fig. 2a). Evans blue staining showed that $\mathrm{Al}$ treatment induced more cell death in WT than in the mutant (Fig. 2a). This result was consistent with the notion that ral1 mutant was more resistant to $\mathrm{Al}$ than WT.

To further compare the Al resistance phenotype of ral1 mutant with WT, we exposed roots of WT and the mutant to a series of $\mathrm{Al}$ concentrations. Root elongation of the mutant was slower than that of the wild-type in the absence of $\mathrm{Al}$ (WT, $40 \pm 6.8 \mathrm{~mm} / 48 \mathrm{~h}$ vs rall, $25 \pm$ $3.7 \mathrm{~mm} / 48 \mathrm{~h}$ ). Longitudinal sections of root meristem and mature zones showed that while root meristem morphology of the mutant did not differ from that of WT (Fig. 3a), root cell length in the mature zone was shorter in the mutant than in WT (Fig. 3b and c), indicating that short root phenotype in the mutant was mainly caused by the defective cell elongation. However, in the presence of $10,20,50$ and $100 \mu \mathrm{M} \mathrm{Al}$, root elongation of WT plants was respectively inhibited by 28,55 , 69 and $85 \%$, whereas that of the mutant was inhibited by $11,30,51$ and $66 \%$, respectively (Fig. $2 b$ ). This result indicates that ral1 mutant was more resistant to $\mathrm{Al}$ than WT. We also compared the $\mathrm{Al}$ resistance of ral1 mutant with two Al-resistant japonica cultivars NPB and Koshi, and the results showed that the mutant was slightly more resistant to $\mathrm{Al}$ than the $\mathrm{Al}$-resistant cultivars (Fig. 2b). Since the differential Al resistance between japonica and indica varieties is controlled by multiple QTLs (Ma and Furukawa 2003), it is unlikely that the high $\mathrm{Al}$ resistance in ral1 mutant was caused by the mutation of one of the Al-sensitive QTLs. To further confirm the increased resistance of ral1 mutant to $\mathrm{Al}$, we grew the mutant and WT plants on an acid soil with a $\mathrm{pH}$ of 4.1 and a neutral soil with a $\mathrm{pH}$ of 6.6. In the neutral soil, the growth rate of the mutant was lower than that of WT (Fig. 2c). In the acid soil, the root growth of WT plants was inhibited by $54 \%$, whereas that of the mutant was stimulated in comparison with its growth on the neutral soil (Fig. 2d).

To examine whether the increased resistance of rall mutant to $\mathrm{Al}$ is specific, we exposed roots of WT and the mutant to other toxic metals including $\mathrm{Cd}$ and La. At $5 \mu \mathrm{M}$ $\mathrm{La}$, inhibition of root elongation in the mutant was not significantly different from that in WT (Fig. 4). By contrast, $5 \mu \mathrm{M} \mathrm{Cd}$ inhibited 60 and $14 \%$ of the root elongation in WT and the mutant, respectively. These results revealed that the mutant was also more resistant to $\mathrm{Cd}$.

\section{Al Accumulation Pattern of ral1 Mutant}

To investigate whether $\mathrm{Al}$ accumulation in ral1 mutant was altered or not, roots of WT and the mutant were exposed to $20 \mu \mathrm{M} \mathrm{Al}$ for $24 \mathrm{~h}$, and then the roots were stained by an $\mathrm{Al}$ indicator Eriochrome Cyanine $\mathrm{R}$ (ER). While the root tip including root cap, meristem and transition zones was heavily stained in the wild-type, the mutant displayed much lighter color in the root tip (Fig. 5a), indicating that ral1 mutant accumulated less $\mathrm{Al}$ in root tips than WT. Al inhibits root elongation within hours (Ryan et al. 1993; Sivaguru et al. 1999). To determine whether WT and the mutant differ in $\mathrm{Al}$ accumulation in a short term, we exposed the roots to $\mathrm{Al}$ for $6 \mathrm{~h}$ and then measured the total $\mathrm{Al}$ content in root tips $(0-1 \mathrm{~cm})$ and basal roots $(1-2 \mathrm{~cm})$. Results showed that while total $\mathrm{Al}$ content in basal roots of ral1 was similar to that of WT, the mutant accumulated significantly less $\mathrm{Al}$ in root tips than WT (Fig. 5b). These results suggest that reduced $\mathrm{Al}$ accumulation in the root tips was the likely cause of increased $\mathrm{Al}$ resistance in the mutant.

We further fractionated the root segments into cell wall and cell sap to investigate which component accumulated less $\mathrm{Al}$ in the mutant. Results showed that $\mathrm{Al}$ content in the cell wall of the root tips was much lower in rall than in the wild type (Fig. 5c), whereas $\mathrm{Al}$ accumulation in the cell sap was similar between WT and the mutant (Fig. 5d). In the basal roots, $\mathrm{Al}$ accumulation in the cell wall of the mutant did not differ from that of the WT, although the $\mathrm{Al}$ content in the cell sap was 
$\mathbf{a}$

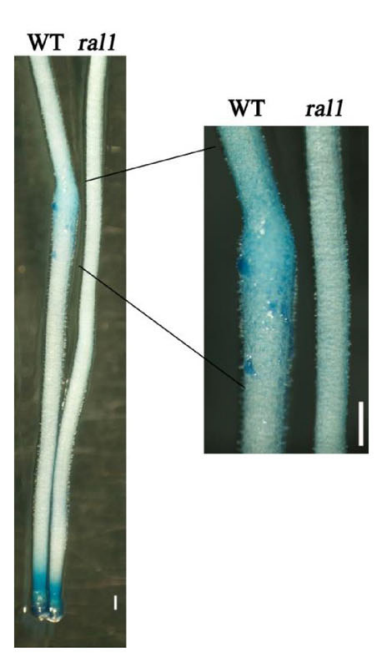

b

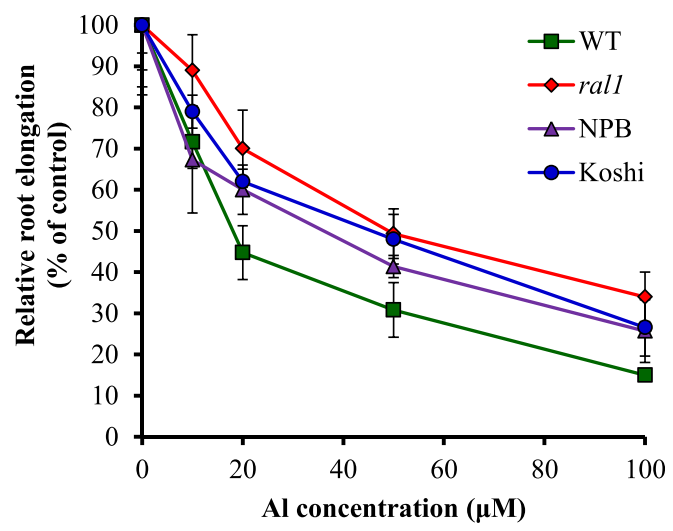

d

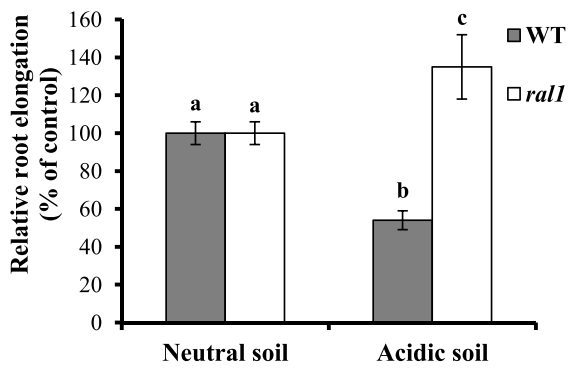

Fig. 2 Comparison of Al resistance phenotype between WT and ral1 mutant. a Evans blue staining. Roots of WT and the mutant were exposed to $20 \mu \mathrm{M}$ Al for $24 \mathrm{~h}$ and then stained with $0.025 \%$ Evans blue. Scale bar $=500 \mu \mathrm{m}$. b A dose-response experiment of Kasalath (WT), ral1 mutant, NPB and Koshi. Seedlings were exposed to a $0.5 \mathrm{mM} \mathrm{CaCl} 2$ solution ( $\mathrm{pH}$ 4.5) containing 0, 10, 20, 50 or $100 \mu \mathrm{M} \mathrm{Al} \mathrm{for} 48$ h. Relative root elongation (RRE) was used to evaluate their resistance to Al. Data are means \pm SD $(n=7)$. $\mathbf{c}, \mathbf{d}$ Comparison of root growth between WT and the mutant on different soils. Germinated seeds were grown on neutral soil $(\mathrm{pH} 6.6)$ or acidic soil $(\mathrm{pH} 4.1)$ for 6 days. Scale bar $=1 \mathrm{~cm}$. Data are means \pm SD $(n=6)$. Means with different letters are significantly different $(P<0.05$, Tukey test)

slightly increased in the mutant compared to the WT (Fig. $5 \mathrm{c}$ and d). These results suggest that the cell wall of ral1 mutant root tips had a reduced capability to bind $\mathrm{Al}$, resulting in increased resistance to $\mathrm{Al}$.

Since ral1 mutant was more resistant to $\mathrm{Cd}$ as well, we want to know whether $\mathrm{Cd}$ accumulation pattern in the mutant was altered or not. Measurement of $\mathrm{Cd}$ content in the cell wall and cell sap revealed that the $\mathrm{Cd}$ accumulation in the two components of root tips was not significantly different between WT and the mutant (Fig. 5e and f), which suggested that the increased resistance of the mutant to $\mathrm{Cd}$ and $\mathrm{Al}$ might be through different mechanisms.

\section{Effect of RAL1 Mutation on The Expression of} Al-resistance Genes in Rice

To investigate whether the rall mutant had altered expression of Al-resistance genes, roots of WT and the mutant were exposed to 0 or $20 \mu \mathrm{M} \mathrm{Al}$ for $6 \mathrm{~h}$ and the expression of Al-resistance genes was determined. Although the expression levels of STAR1, ART1, Nrat1 and ALS1 genes in the mutant were higher than those in WT without Al treatment (Fig. 6), these genes were expressed at a similar level in WT and the mutant under $\mathrm{Al}$ stress. The expression of the other Al-resistance genes OsFRDL4 and OsMGT1 did not differ between WT and the mutant under either $-\mathrm{Al}$ or $+\mathrm{Al}$ conditions 


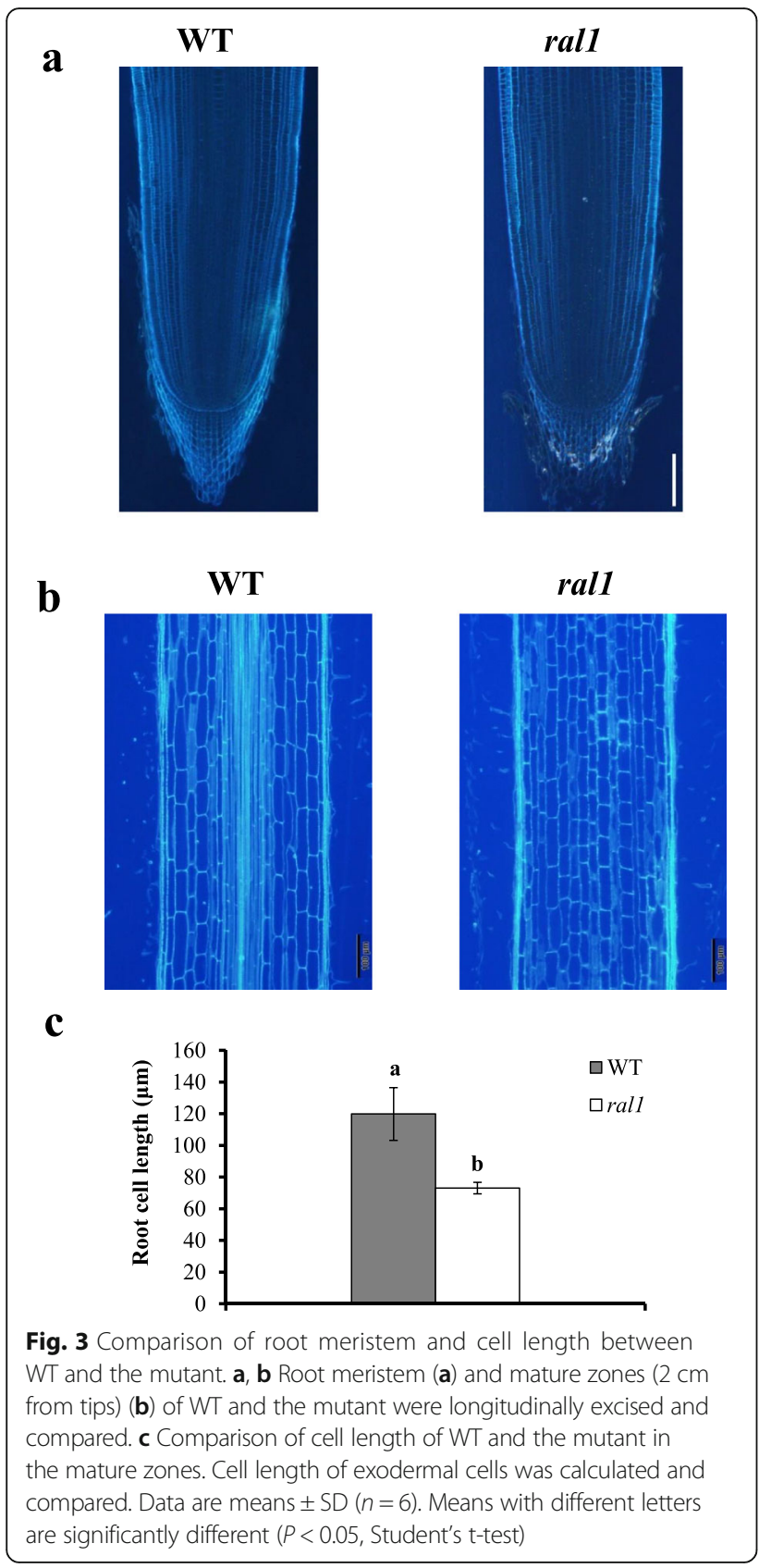

(Fig. 6). These results suggest that increased $\mathrm{Al}$ resistance of ral1 was not through elevated expression of Al-resistance genes.

\section{Genetic Analysis of ral1 Mutant and Molecular Mapping of RAL1 Gene in Rice}

Genetics analysis of ral1 mutant was performed by using an F2 population from a backcross between ral1 and its wild type Kasalath. Of 148 F2 seedlings, 43 seedlings showed $\mathrm{Al}$ resistance $(\mathrm{RRE}>65 \%)$ and short root phenotype in the absence of $\mathrm{Al}$ (Fig. 6a), whereas the remaining 105 seedlings with normal root elongation

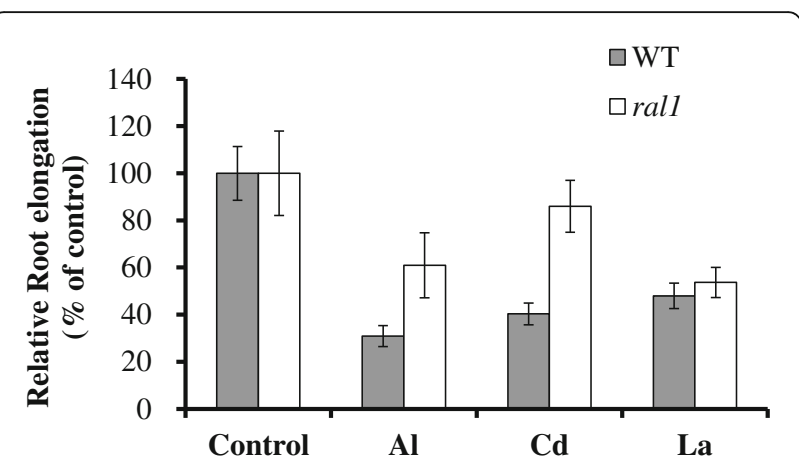

Fig. 4 Sensitivity to other metals. Seedlings of WT and ral1 mutant were exposed for a $0.5 \mathrm{mM} \mathrm{CaCl}_{2}$ solution ( $\mathrm{pH}$ 4.5) containing 0 , $20 \mu \mathrm{M} \mathrm{Al}, 5 \mu \mathrm{M} \mathrm{Cd}, 5 \mu \mathrm{M}$ La for $48 \mathrm{~h}$. Data are means \pm SD $(n=8)$. Relative root elongation (RRE) was used to evaluate their sensitivity to Al. Means with different letters are significantly different $(P<0.05$, Tukey test)

were intolerant to $\mathrm{Al}(\mathrm{RRE} \leq 65 \%)$. The segregation pattern was consistent with $1: 3$ ratio $\left(\chi^{2}=0.62, P>0.05\right)$, suggesting that the $\mathrm{Al}$ resistance and short root phenotype in ral1 mutant was controlled by a single recessive gene.

To map the responsible gene, we constructed an F2 population derived from a cross between the mutant and an indica cultivar HJX74. Since the Al resistance and short root phenotype was co-segregated and controlled by the same gene (Fig. 7a), we evaluated the phenotype of each F2 plant based on the short root appearance. In the ral1/HJX74 F2 population, 64 of 247 plants showed the short root phenotype, which also agreed to a single gene segregation pattern $\left(\chi^{2}=0.03\right.$, $P>0.05)$. Bulked segregant analysis with 54 polymorphic markers covering the whole rice genome was used to determine the chromosome location of RAL1 and a SSR polymorphic marker Os06g004 on the long arm of chromosome 6 was found to be linked to the gene (Fig. 6b). To further map the gene, 50 F2 mutants and six polymorphic markers around $R A L 1$ gene were used. Linkage analysis indicated that $R A L 1$ gene was located between the two markers Os06g005 and Os06g006 on the long arm of chromosome 6 , with a genetic distance of 5.0 and $7.0 \mathrm{cM}$, respectively (Fig. 6b). The marker Os06g003 on $104 \mathrm{cM}$ position of RGP map was tightly linked to the gene.

\section{Discussion}

In this study, we found that $\mathrm{Al}$ toxicity can induce root swelling in Al-intolerant indica cultivars including Kasalath (Fig. 1a), but not in Al-resistant japonica cultivars (Fig. 1b). Al-induced root swelling can also occur in soybean (Kopittke et al. 2015), which is less resistant to $\mathrm{Al}$ than rice. These observations suggest that $\mathrm{Al}$-induced root swelling is not a universal phenomenon, but appears to occur preferentially in Al-intolerant plant 

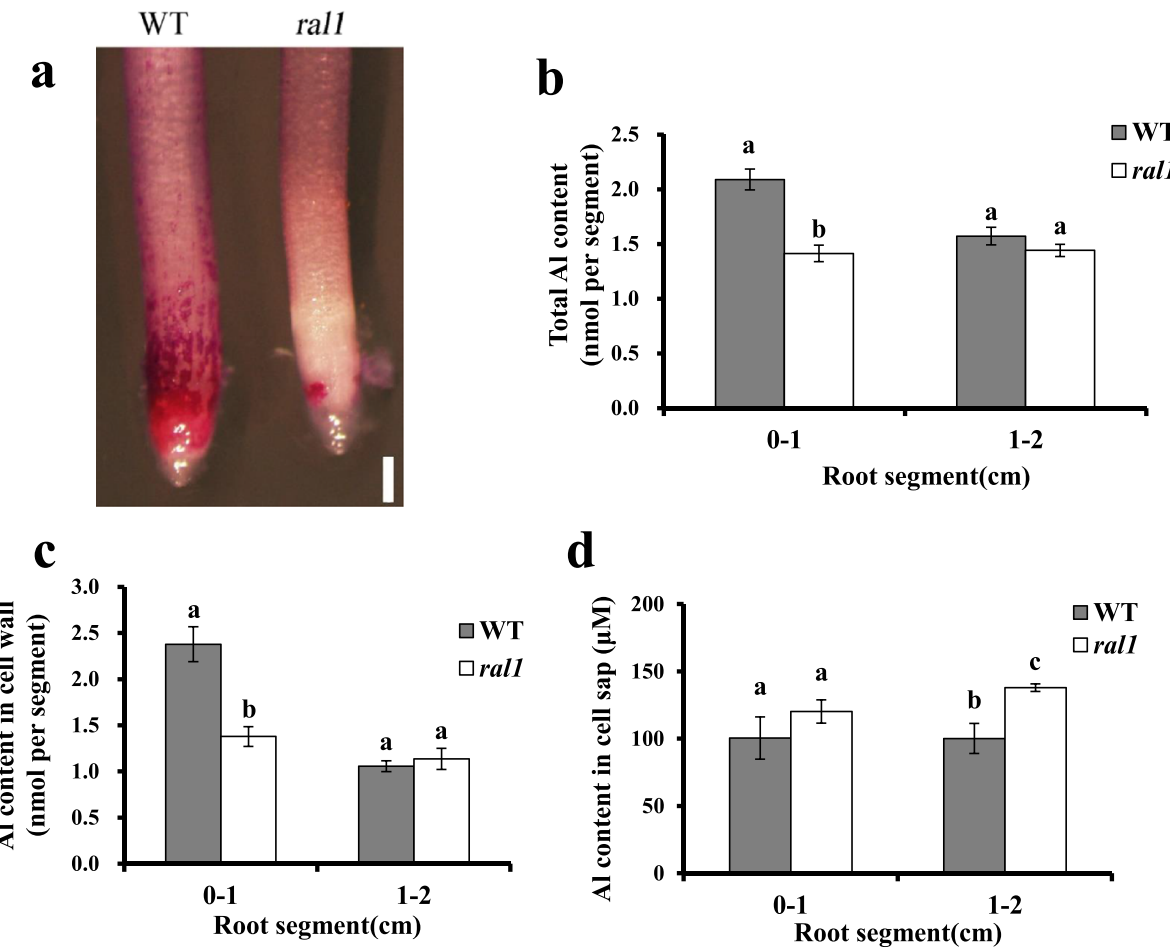

d

e

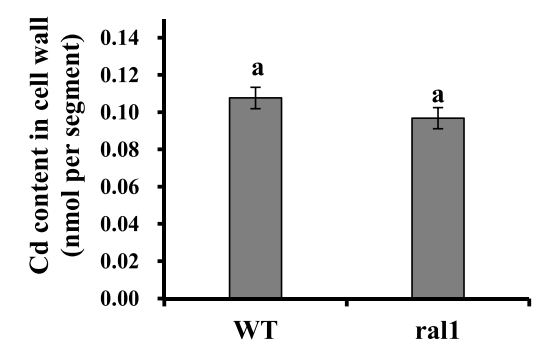

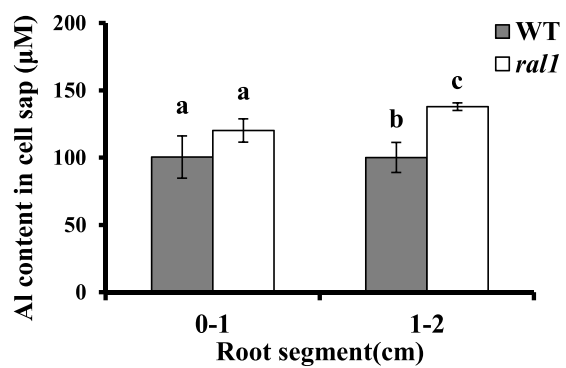

f

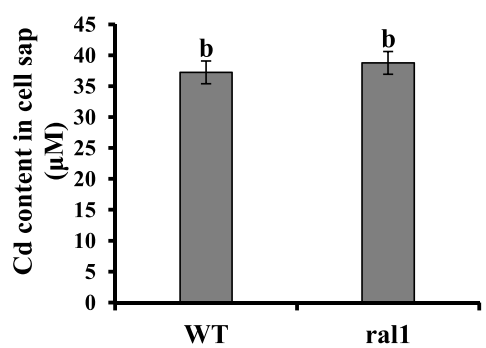

Fig. 5 Comparison of Al and Cd accumulation pattern between WT and ral1 mutant. a Eriochrome Cyanine R staining of WT and rall mutant after $20 \mu \mathrm{M} \mathrm{Al}$ treatment for $24 \mathrm{~h}$. Scale bar $=200 \mu \mathrm{m}$. b-d Comparison of total Al content (b), Al content in cell wall (c), and Al content in cell sap (d) in different root segments of WT and the mutant. Seedlings were exposed to a $0.5 \mathrm{mM} \mathrm{CaCl}_{2}$ solution containing $20 \mu \mathrm{M} \mathrm{Al}$ at pH 4.5 for $6 \mathrm{~h}$. Root tips $(0-1 \mathrm{~cm})$ and basal roots $(1-2 \mathrm{~cm})$ were excised for Al determination. e, $\mathbf{f}$ Comparison of $\mathrm{Cd}$ content in cell wall $(\mathbf{e})$ and $\mathrm{Cd}$ content in cell sap (f) in root tips of WT and the mutant. Seedlings were exposed to a $0.5 \mathrm{mM} \mathrm{CaCl}_{2}$ solution containing $5 \mu \mathrm{M} \mathrm{Al}$ at pH 4.5 for 6 h. Data are means \pm SD $(n=3)$. Means with different letters are significantly different $(P<0.05$, Tukey test)

species. In support of this hypothesis, Al-induced root swelling does not occur in the Al-resistant mutant ral1 isolated in the present study (Fig. 2a). The burst of ethylene evolution induced by $\mathrm{Al}$ stress is suggested to be responsible for the $\mathrm{Al}$-induced root swelling in soybean (Kopittke et al. 2015). Our results also showed that inhibition of ethylene production by AVG treatment could suppress the $\mathrm{Al}$-induced root swelling and ameliorate Al-induced root growth inhibition (Fig. 1d and e). These suggest that $\mathrm{Al}$-induced ethylene production that causes the root swelling is conserved in $\mathrm{Al}$-intolerant varieties of both dicots and monocots.
Because of the difference among individual plants in the seed germination and root elongation rate, it is difficult to directly compare the root elongation rate between plants after Al treatment. Therefore, root length of individual plants is usually measured before and after $\mathrm{Al}$ treatment for the calculation of root elongation during the treatment period ( $\mathrm{Ma}$ et al. 2005; Huang et al. 2009b). This screening method is therefore laborintensive and inefficient. In the present study, we found that $\mathrm{Al}$ induced root swelling in the indica variety Kasalath. The point of swelling serves as a marker for the initial position of root growth before $\mathrm{Al}$ treatment. 

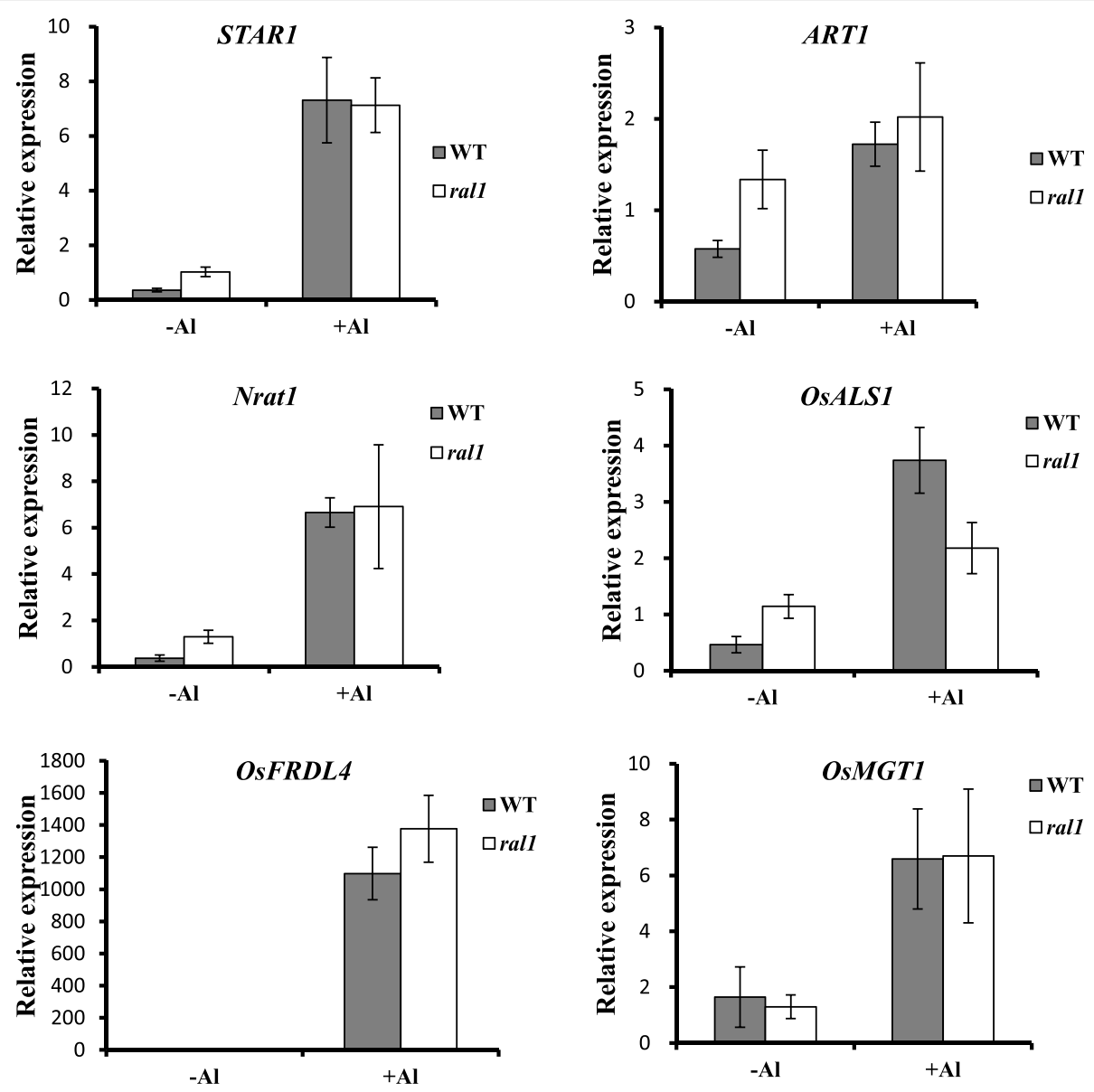

Fig. 6 Expression pattern of Al-resistance genes in WT and ral1 mutant. Seedlings were exposed to 0 or $20 \mu \mathrm{M} \mathrm{Al} \mathrm{for} 6 \mathrm{~h}$ and root tips (0-2 cm) were excised for RNA isolation and CDNA synthesis. The expression of Al-resistance genes indicated on the top of each panel was determined by real-time RT-PCR and Histone H3 was used as an internal control. The data were normalized to the expression of each gene in the mutant without Al treatment

Root elongation from this marker after Al treatment could be assessed quickly by visual inspection without the need to measure the root length twice. By this simple and efficient method, we are able to screen $\sim 5000$ M2 lines and isolated 11 mutants with altered Al sensitivity. Among them, one had a mutation in the coding sequence of OsALS1, whilst the others did not have mutations in the known Al-resistance genes (Data not shown), which suggests that our new screening method is feasible and highly efficient.

Although we evaluated $\mathrm{Al}$ resistance based on relative root elongation and root growth of ral1 mutant was slower than that of WT under control condition, we do not think that less root growth without $\mathrm{Al}$ treatment is necessarily correlated with higher relative root elongation under $\mathrm{Al}$. In fact, we also isolated several additional short root mutants with altered Al sensitivity. Although they showed slower root growth under control condition, these mutants are more sensitive to $\mathrm{Al}$ than WT instead of more resistance to $\mathrm{Al}$ because they had lower relative root elongation under $\mathrm{Al}$ treatment (Data not shown). Therefore, higher relative root elongation in ral1 mutant compared to WT under both hydroponic culture and acidic soil growth conditions indicates that ral1 is an Al-resistant mutant. Further work revealed that ral1 accumulated less $\mathrm{Al}$ in the cell wall of root tips than in WT, while the Al content in the cell sap was similar between the mutant and WT. This difference suggests that reduced $\mathrm{Al}$ binding to the cell wall is responsible for the increased $\mathrm{Al}$ resistance in the mutant. Al-resistant cultivars of maize, rice and common bean are also documented to accumulate less $\mathrm{Al}$ in the cell wall of root tips than the Al-sensitive ones (Eticha et al. 2005; Yang et al. 2008; Rangel et al. 2009), and differences in the proportion of low-methylated pectin are suggested to be responsible for the varietal differences in $\mathrm{Al}$ resistance. It remains to be demonstrated whether the increased resistance of rall mutant to $\mathrm{Al}$ is also through the alteration of cell-wall pectin content and/or the degree of pectin methylation. Recently, Zhu et al. 

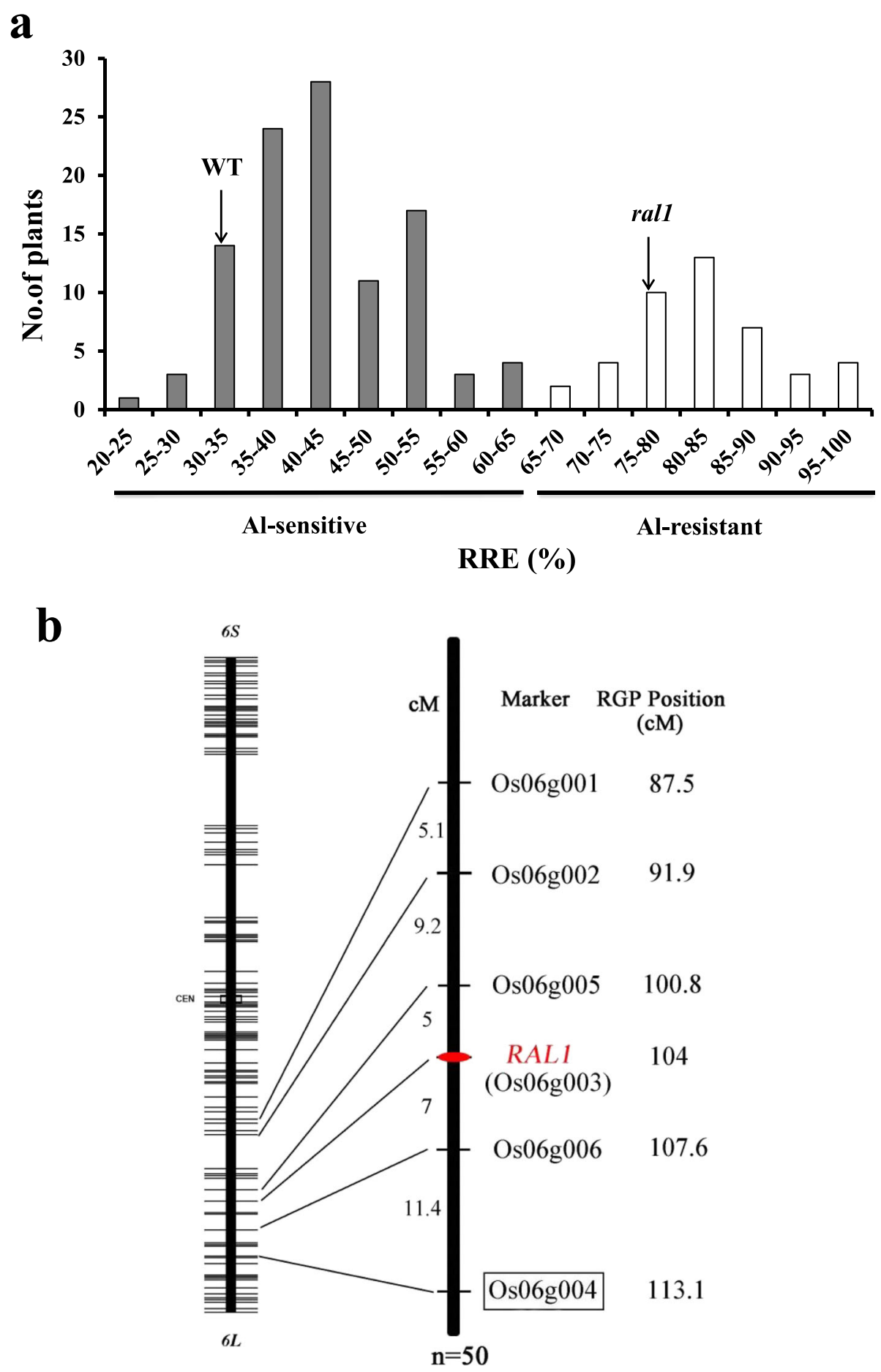

Fig. 7 Genetic analysis and molecular mapping of ral1. a Frequency distribution of Al sensitivity and short root phenotype in ral1/WT F2 population. A total 148 F2 seedlings were exposed to $-\mathrm{Al}$ condition for $24 \mathrm{~h}$ and exposed to $+\mathrm{Al}(20 \mu \mathrm{M})$ condition for a further $24 \mathrm{~h}$. Normal-root plants (Gray bar) and short-root plants (White bar) was determined based on that root elongation was more than $13 \mathrm{~mm}$ and less than $10 \mathrm{~mm}$ at the first $24 \mathrm{~h}$, respectively. Relative root elongation (RRE) was used to evaluate their sensitivity to Al. b Molecular mapping of ral1. Bulked segregant analysis was used to determine the chromosome location of rall and a polymorphic marker Os06g004 boxed was found to be linked. Fifty $F_{2}$ plants with short roots and five additional markers were used to further map the gene. Left bar represents the chromosome 6 downloaded from RGP website (http://rgp.dna.affrc.go.jp). Genetic distance (cM) between neighboring makers and RGP genetic position (CM) were also indicated 
(2012) reported that mutation of $X T H 31$, a xyloglucan endotransglucosylase-hydrolase gene, also results in increased resistance to $\mathrm{Al}$ in Arabidopsis thaliana, which is caused by a decrease of root xyloglucan content and associated cell wall $\mathrm{Al}$ accumulation in the mutant. Unlike $x$ th 31 mutant where the Al content of the whole roots is decreased nearly three folds, our ral1 mutant had reduced $\mathrm{Al}$ accumulation only in the root tips. In addition, ral1 mutant is resistant not only to $\mathrm{Al}$ but also to $\mathrm{Cd}$. These data suggest that Al-resistance mechanism of ral1 is likely to be different from that of $x$ th 31 .

Although organic acid anions do not play a major role in the detoxification of $\mathrm{Al}$ in rice ( $\mathrm{Ma}$ et al. 2002), $\mathrm{Al}$ induced citrate secretion through OsFRDL4 transporter contributes to the $\mathrm{Al}$ resistance (Yokosho et al. 2011). Our expression analysis showed that the expression of OsFRDL4 in ral1 mutant was similar to that in WT (Fig. 5), suggesting that increased resistance of the mutant to $\mathrm{Al}$ was not through $\mathrm{Al}$-activated citrate exudation pathway. Expression analysis of other known Alresistance genes in rice also reveals that the increased resistance of ral1 to $\mathrm{Al}$ does not appear to be through enhanced expression of those Al-resistance genes. Subsequently, we used a map-based cloning approach to isolate the responsible gene and mapped the gene to the long arm of chromosome 6. Although the Al-resistance gene STAR1 is also located on the long arm of chromosome 6 (Ma et al. 2005; Huang et al. 2009a), the genetic distance of RAL1 and STAR1 in RGP genetic map (http://rgp.dna.affrc.go.jp) was different. RAL1 was mapped between Os06g005 (100.8 cM) and Os06g006 (107.6 cM) (Fig. 7b), while STAR1 gene is located at $115.6 \mathrm{cM}$. Furthermore, the coding sequence and expression level of STAR1 was not altered in the mutant (Fig. 5 and data not shown). These indicate that $R A L 1$ is a novel Al-resistance gene in rice.

\section{Conclusion}

We develop a highly efficient method to screen Alsensitive or -resistant mutants in rice. Using this method, we identify a novel mutant resistant to $\mathrm{Al}$. Physiological analysis reveals that decreased Al binding capacity to the cell wall is responsible for the increased resistance of ral1 mutant to Al. RAL1 gene is mapped on the long arm of chromosome 6 , and cloning of the gene is currently undertaken.

\section{Methods}

\section{Al-induced Root Swelling in Different Rice Cultivars}

For root swelling experiment, 8 indica and 4 japonica cultivars were used. The indica varieties were Kasalath, Huagengxian74 (HJX74), Zhong4188 (Z4188), BG367, Zihui100 (ZH100), IR64, Zhongjiazai17 (ZJZ17) and 9311, and the japonica cultivars were Nipponbare (NPB),
Huayang (HY), Koshihikari (Koshi) and Zhonghua11 (ZH11). Five-day old seedlings were exposed to a $0.5 \mathrm{mM} \mathrm{CaCl} 2$ solution containing $0,10,20,50$ or $100 \mu \mathrm{M} \mathrm{AlCl} 3$ for $72 \mathrm{~h}$. Root swelling phenotype was observed under a stereo microscope (SZX7, Olympus).

\section{Construction of a Mutant Library and Screening of Rice Mutants with Altered Al Sensitivity}

For mutant library construction, seeds of an Alintolerant indica cultivar (cv. Kasalath) were soaked in tap water for $8 \mathrm{~h}$ at room temperature. After soaking, the seeds were treated with $1 \%$ ethylmethylsulfone (EMS) solution for $8 \mathrm{~h}$, which inhibited seed germination rate by $50-60 \%$. The seeds were then washed to remove residual EMS and incubated at $37{ }^{\circ} \mathrm{C}$ overnight. Germinated seeds were sowed and grown in a paddy field to harvest $M_{2}$ seeds from each $M_{1}$ plant. For initial mutant screening, 16 seeds each of $36 \mathrm{M}_{2}$ line were put in 96-well PCR plates that were floated on a $0.5 \mathrm{mM}$ $\mathrm{CaCl}_{2}$ solution in a $10 \mathrm{l}$ container at $25^{\circ} \mathrm{C}$. After growth for 5 days, seedlings were exposed to a $0.5 \mathrm{mM} \mathrm{CaCl}_{2}$ solution ( $\mathrm{pH} 4.5$ ) containing $20 \mu \mathrm{M} \mathrm{AlCl}_{3}$ for $3 \mathrm{~d}$. Because $20 \mu \mathrm{M} \mathrm{AlCl} \mathrm{Al}_{3}$ could induce swelling of each root, root elongation after $\mathrm{Al}$ treatment was roughly estimated based on the distance between the root swelling position and root tips by eye. Root elongation with decreased or increased more than 2 folds was used as a parameter to select Al-sensitive or Alresistant candidate mutants, respectively. Mutants that did not show root swelling after exposure to $\mathrm{Al}$ were also retained.

For the second screening, $M_{3}$ generation of candidate mutants were harvested and used to evaluate their sensitivity to $\mathrm{Al}$. Briefly, $\mathrm{M}_{3}$ seeds of each candidate mutant were soaked in deionized water for $2 \mathrm{~d}$ at $37{ }^{\circ} \mathrm{C}$. The seeds were then placed on a net floating on a $0.5 \mathrm{mM}$ $\mathrm{CaCl}_{2}$ solution in a $2.5 \mathrm{l}$ container. After growth at $25^{\circ} \mathrm{C}$ for $3 \mathrm{~d}, 10$ seedlings each were exposed to a $0.5 \mathrm{mM}$ $\mathrm{CaCl}_{2}$ solution containing 0,20 or $50 \mu \mathrm{M} \mathrm{AlCl}$ at $\mathrm{pH} 4.5$ for $48 \mathrm{~h}$. The root length was measured with a ruler before and after Al treatment. Relative root elongation (RRE) was expressed as (root elongation with $\mathrm{Al}$ treatment/root elongation without $\mathrm{Al}) \times 100$. Lines with lower or higher RRE than WT at either 20 or $50 \mu \mathrm{M}$ $\mathrm{AlCl}_{3}$ were regarded as Al-sensitive or -resistant mutants, respectively.

\section{Aminoethoxyvinylglycine (AVG) Treatment}

For aminoethoxyvinylglycine treatment, Kasalath seedlings were exposed to a $0.5 \mathrm{mM} \mathrm{CaCl}_{2}$ solution containing $0,0.1,0.2$ or $0.5 \mu \mathrm{M}$ AVG and with or without $20 \mu \mathrm{M} \mathrm{AlCl}$ for $24 \mathrm{~h}$. Root swelling and $\mathrm{Al}$ resistance between different treatments were compared. 
Root Meristem and Cell Length Comparison

To compare the difference of root meristem and cell length between WT and ral1 mutant, root tips and basal roots (2 cm from tips) were excised and immersed in FAA solution (70 \%) under vacuum condition for $12 \mathrm{~h}$. The roots were treated with $70 \%$ ethanol and then subjected to an acetone series (70, 80, 90, 95 and $100 \%)$, and thereafter transferred to a series of acetone/Epon 812 resin solution with different ratios (3:1, 1:1 and 1:3). Finally, the roots were embedded in Epon812 resin for at least $48 \mathrm{~h}$ and cut longitudinally into $5 \mu \mathrm{m}$ slices with an ultramicrotome (Lecia EM UC7). Cell wall autofluorescence and cell length of root sections was observed with a microscope (BX 53 microscope, Olympus).

\section{Evaluation of Resistance to Al and Other Metals}

For a dose-response experiment, 8 seedlings each of WT (cv. Kasalath) and ral1 mutant were exposed to a $0.5 \mathrm{mM} \mathrm{CaCl}_{2}$ solution containing $0,10,20,50$ or $100 \mu \mathrm{M} \mathrm{Al} \mathrm{Cl}$ at $\mathrm{pH} 4.5$ for $48 \mathrm{~h}$. Relative root elongation (RRE) described above was used to evaluate the resistance to $\mathrm{Al}$. For comparison of the resistance of WT and the mutant to other metals, seedlings were exposed to $0.5 \mathrm{mM} \mathrm{CaCl}_{2}$ solutions containing 0, $20 \mu \mathrm{M} \mathrm{AlCl} \mathrm{Al}_{3}$, $5 \mu \mathrm{M} \mathrm{CdCl}$ or $5 \mu \mathrm{M} \mathrm{LaCl}_{3}$ for $48 \mathrm{~h}$ and RRE was used to evaluate their resistance to the metals.

To further evaluate the Al resistance, germinated seeds of WT and ral1 mutant were sown in an acidic soil ( $\mathrm{pH} 4.1)$ and a neutral soil ( $\mathrm{pH}$ 6.6), which were collected from different regions of China. After growth for 6 days, the root length was measured and compared.

\section{Evans Blue and Eriochrome Cyanine R Staining}

Five-day-old seedlings of WT and ral1 mutant were exposed to a $0.5 \mathrm{mM} \mathrm{CaCl}_{2}$ solution ( $\mathrm{pH} 4.5$ ) containing $20 \mu \mathrm{M} \mathrm{Al}$ for $24 \mathrm{~h}$, and then the roots were stained with 0.025 \% Evans blue or 0.1 \% Eriochrome Cyanine R for $10 \mathrm{~min}$. After staining, roots were washed with distilled water for $10 \mathrm{~min}$ and photographed by the stereo microscope.

\section{Determination of $\mathrm{Al}$ and $\mathrm{Cd}$ Content}

To determine $\mathrm{Al}$ content in roots, seedlings of WT and ral1 mutant were exposed to a $0.5 \mathrm{mM} \mathrm{CaCl}_{2}$ solution containing $20 \mu \mathrm{M} \mathrm{Al}$ for $6 \mathrm{~h}$. Root tips $(0-1 \mathrm{~cm})$ and basal roots $(1-2 \mathrm{~cm})$ were excised and placed in a plastic tube containing $0.5 \mathrm{ml}$ of $2 \mathrm{M} \mathrm{HNO}_{3}$. The tubes were votexed five times during a $48 \mathrm{~h}$ period. The $\mathrm{Al}$ concentration in the solution was measured by inductively coupled plasma mass spectrometry (ICP-MS, Perkin Elmer NexIon300). Measurement of the $\mathrm{Al}$ or $\mathrm{Cd}$ content in different compartments was performed according to Xia et al. (2010). Briefly, root tips or basal roots of WT and the mutant treated with $20 \mu \mathrm{M} \mathrm{Al}$ or $5 \mu \mathrm{M} \mathrm{Cd}$ for $6 \mathrm{~h}$ were put in Milipore Ultrafree-MC Centrifugal filter units. The samples were first centrifuged at $3000 \mathrm{~g}$ for $10 \mathrm{~min}$ at $4{ }^{\circ} \mathrm{C}$ to remove the apoplastic fluid and then the rest samples were kept at $-80{ }^{\circ} \mathrm{C}$ overnight. The frozen samples were thawed at room temperature and centrifuged at $15,000 \mathrm{rpm}$ for $10 \mathrm{~min}$ to collect the cell sap. The obtained cell sap was transferred to a new $1.5 \mathrm{ml}$ tube containing $0.5 \mathrm{ml}$ of $0.1 \mathrm{M} \mathrm{HNO}_{3}$ for the $\mathrm{Al}$ determination. The residual cell wall was washed with $70 \%$ ethanol, vortexed and centrifuged at 15,000 rpm for $5 \mathrm{~min}$. After three rounds of washing, the cell wall was immersed in $0.5 \mathrm{ml}$ of $2 \mathrm{M} \mathrm{HNO}_{3}$ for at least $24 \mathrm{~h}$ with occasional votexing. The $\mathrm{Al}$ or $\mathrm{Cd}$ concentration in the solution was determined by ICP-MS.

\section{RNA Isolation and Quantitative RT-PCR Analysis}

To examine the expression pattern of Al-resistance genes in WT and ral1 mutant, 5-day-old seedlings were exposed to a $0.5 \mathrm{mM} \mathrm{CaCl} 2$ solution containing 0 or $20 \mu \mathrm{M} \mathrm{Al}$ at $\mathrm{pH} 4.5$ for $6 \mathrm{~h}$ and then root tips $(0-2 \mathrm{~cm})$ were excised for RNA isolation. Total RNA was extracted using a Universal Plant Total RNA Extraction Kit (BioTeke, http://www.bioteke.com). One microgram of total RNA was used for first strand cDNA synthesis by using HiScript II Q Select RT SuperMix (Vazyme, http://www.vazyme.com), following the instruction manual of the kit with an oligo $(\mathrm{dT})_{20}$ primer. The primer sequences for real-time RT-PCR analysis of Al-resistance genes were as follows: STAR1 (Forward, 5'-TCGCAT TGGCTCGCA CCCT-3'; Reverse, 5'-TCGTCTTCTTC AGCCGCACGAT-3'), ART1 (Forward, 5'-CAGTGCT TCTCGTGGGTCTT-3'; Reverse, 5' -CCTGTGCGTGA AGAACCAC T-3'), Nrat1 (Forward, 5' -GCAAAGCACCACTATCAG-3'; Reverse, 5'-GAA CTTGAGTAGAG GGATG-3'), OsALS1 (Forward, 5'-GGTCGTCAGTCTC TGCC TTGTC-3'; Reverse, 5'-CCTCCCCATCATTTT CATTTGT-3'), OsFRDL4 (Forward, 5' -CGTCATCAG CACCATCCACAG-3'; Reverse, 5'-TCATTTGCGAA GAAACTTCCACG-3'), OsMGT1 (Forward, 5'-GAGG GTGGAGTTTGGGAA GC-3'; Reverse, 5' -CCCTGGA GCCTGACGACGATG-3'), OsCDT3 (Forward, 5'-ATG TACAACCCTCCGGCGGC-3'; Reverse, 5'-TCAGCAG CAGCAGAGGC ATTCG-3'), and the sequences of internal control Histone $H 3$ were 5'-GGTCAACTTGTT GATTCCCCTCT-3' and 5'-AACCGCAAAATCCAAA G AACG-3'. Data were collected in accordance with CFX96 Touch real-time PCR detection system (BioRad).

\section{Genetic Analysis and Molecular Mapping}

For genetic analysis of ral1 mutant, an F2 population from a cross between mutant and WT (cv. Kasalath) was used. Seedlings of F2 and their parents were exposed to a $0.5 \mathrm{mM} \mathrm{CaCl}_{2}$ solution at $\mathrm{pH} 4.5$ for $24 \mathrm{~h}$. Root length was measured before and after treatment, and calculated 
root elongation was used to evaluate the short root phenotype of each individual in comparison with their parents. The seedlings were then exposed to a $0.5 \mathrm{mM}$ $\mathrm{CaCl}_{2}$ solution ( $\mathrm{pH}$ 4.5) containing $20 \mu \mathrm{M} \mathrm{Al}$ for another $24 \mathrm{~h}$. Relative root elongation (RRE) was used to determine the sensitivity of each seedling to $\mathrm{Al}$ stress.

For mapping of ral1 mutant gene, an F2 population from a cross between ral1 and another indica cultivar HJX74 was used. Bulked segregant analysis (BSA) by pooling equal amounts of DNA from 20 short-root or 20 normal-root plants was used to determine the chromosome location of the mutant gene. The polymorphic markers used for BSA were derived from published high-density SSR markers (McCouch et al. 2002). To further map the gene, linkage analysis was carried out by using $50 \mathrm{~F} 2$ mutants and six polymorphic markers. The primer sequences of the six markers are as follows: Os06g001 (Forward, 5'-ACAAGCAAAGCAAGTCCAT TC-3'; Reverse, 5' -TGGTGAGAACTCCCAAGGCT3'), Os06g002 (Forward, 5'-GAATTGCCGTA TGTCG GAGTC-3'; Reverse, 5'-GGACAAATAATGGGAGCC TTG-3'), Os06g003 (Forward, 5'-AATCTTCATGCCTT TGTCGC-3'; Reverse, 5' -GGTGCTATGTTG GTTTTC CTG-3'), Os06g004 (Forward, 5'-GGTAAATGGAC AATCCTATGGC-3'; Reverse, 5'-GGTAAATGGACA ATCCTATGGC-3'), Os06g005 (Forward, 5' -GGCATCC AATTTTACCCCTC-3'; Reverse, 5'-AAATGGAGCAT GGAGGTC AC-3'), and Os06g006 (Forward, 5'-GAT GATCCATGCTTTGGCC-3'; Reverse, 5'-TTCCAGCA GAAAGAA GACGC-3'). Multipoint linkage analysis was performed using MAPMAKER Version 3.0 (Lander et al. 2009).

\section{Abbreviations \\ ABC: ATP-binding cassette; Al: Aluminum; AVG: Aminoethoxyvinylglycine; BSA: Bulked segregant analysis; EMS: Ethylmethylsulfone; ER: Eriochrome Cyanine R; ICP-MS: Inductively coupled plasma mass spectrometry; ral1: Resistance to aluminum toxicity; RRE: Relative root elongation; WT: Wild-type}

\section{Acknowledgements}

This work was supported by the National Natural Science Foundation of China (Grant No. 31272224 to C.-F. H.), the Fundamental Research Funds for the Central Universities (Grant No. KJJQ201601 and KYTZ201404), Jiangsu Science Fund for Distinguished Young Scholars (Grant No. BK20150027), and the Open Project Program of the State Key Laboratory Breeding Base for Zhejiang Sustainable Pest and Disease Control (Grant No. 2010DS700124KF1604), Zhejiang Academy of Agricultural Sciences.

\section{Authors' Contributions \\ CFH designed and supervised the research, and drafted the manuscript SL performed most of the work. HG, XW, QF, YL and LC participated in construction and screen of the mutant library and genetic analysis of ral1 mutant. SL and FJZ helped to analyze the data and write the manuscript. All authors read and approved the final manuscript.}

\section{Competing Interests}

The authors declare that they have no competing interests.

Received: 5 December 2015 Accepted: 27 October 2016 Published online: 11 November 2016

\section{References}

Arenhart RA, Bai Y, de Oliveira LFV, Neto LB, Schunemann M, Maraschin FD, Mariath J, Silverio A, Sachetto-Martins G, Margis R, Wang ZY, Margis-Pinheiro M (2014) New insights into aluminum resistance in rice: The ASR5 protein binds the STAR1 promoter and other aluminum-responsive genes. Mol Plant 7(4):709-721. doi:10.1093/mp/sst160

Arenhart RA, De Lima JC, Pedron M, Carvalho FEL, Da Silveira JAG, Rosa SB, Caverzan A, Andrade CMB, Schunemann M, Margis R, Margis-Pinheiro M (2013) Involvement of ASR genes in aluminium resistance mechanisms in rice. Plant Cell Environ 36(1):52-67. doi:10.1111/j.1365-3040.2012.02553.x

Chen ZC, Yamaji N, Motoyama R, Nagamura Y, Ma JF (2012) Up-regulation of a magnesium transporter gene OSMGT1 is required for conferring aluminum resistance in rice. Plant Physiol 159(4):1624-1633. doi:10.1104/ pp.112.199778

Delhaize E, Ryan PR, Randall PJ (1993) Aluminum resistance in wheat (Triticum aestivum L.) (II. Aluminum-stimulated excretion of malic-acid from root apices). Plant Physiol 103(3):695-702. doi:10.1104/pp.103.3.695

Eticha D, Stass A, Horst WJ (2005) Cell-wall pectin and its degree of methylation in the maize root-apex: significance for genotypic differences in aluminium resistance. Plant Cell Environ 28(11):1410-1420. doi:10.1111/j.1365-3040.2005. 01375.x

Furukawa J, Yamaji N, Wang H, Mitani N, Murata Y, Sato K, Katsuhara M, Takeda K, Ma JF (2007) An aluminum-activated citrate transporter in barley. Plant Cell Physiol 48(8):1081-1091. doi:10.1093/pcp/pcm091

Hoekenga OA, Vision TJ, Shaff JE, Monforte AJ, Lee GP, Howell SH, Kochian LV (2003) Identification and characterization of aluminum resistance loci in Arabidopsis (Landsberg erecta $\times$ Columbia) by quantitative trait locus mapping. A physiologically simple but genetically complex trait. Plant Physiol 132(2):936-948. doi:10.1104/pp.103.023085

Huang CF, Yamaji N, Chen Z, Ma JF (2012a) A tonoplast-localized half-size ABC transporter is required for internal detoxification of aluminum in rice. Plant J 69 (5):857-867. doi:10.1111/j.1365-313X.2011.04837.x

Huang CF, Yamaji N, Ma JF (2010) Knockout of a bacterial-type ATP-binding cassette transporter gene, AtSTAR1, results in increased aluminum sensitivity in Arabidopsis. Plant Physiol 153(4):1669-1677. doi:10.1104/pp. 110.155028

Huang CF, Yamaji N, Mitani N, Yano M, Nagamura Y, Ma JF (2009a) A bacterialtype $\mathrm{ABC}$ transporter is involved in aluminum resistance in rice. Plant Cell 21 (2):655-67. doi:10.1105/tpc.108.064543

Huang CF, Yamaji N, Nishimura M, Tajima S, Ma JF (2009b) A rice mutant sensitive to Al toxicity is defective in the specification of root outer cell layers. Plant Cell Physiol 50 (5):976-85. doi:10.1093/pcp/pcp050

Huang CF, Yamaji N, Ono K, Ma JF (2012b) A leucine-rich repeat receptor-like kinase gene is involved in the specification of outer cell layers in rice roots. Plant J 69 (4):565-76. doi:10.1111/j.1365-313X.2011.04824.x

luchi S, Koyama H, luchi A, Kobayashi Y, Kitabayashi S, Ikka T, Hirayama T, Shinozaki K, Kobayashi M (2007) Zinc finger protein STOP1 is critical for proton resistance in Arabidopsis and coregulates a key gene in aluminum resistance. Proc Natl Acad Sci U S A 104(23):9900-9905. doi:10.1073/pnas. 0700117104

Kopittke PM, Moore KL, Lombi E, Gianoncelli A, Ferguson BJ, Blamey FP, Menzies NW, Nicholson TM, McKenna BA, Wang P, Gresshoff PM, Kourousias G, Webb Rl, Green K, Tollenaere A (2015) Identification of the primary lesion of toxic aluminum in plant roots. Plant Physiol 167(4):1402-1411. doi:10.1104/pp.114. 253229

Lander ES, Green P, Abrahamson J, Barlow A, Daly MJ, Lincoln SE, Newberg LA (2009) MAPMAKER: An interactive computer package for constructing primary genetic linkage maps of experimental and natural populations (vol 1 pg 174, 1987). Genomics 93(4):398-398. doi:10.1016/j.ygeno.2008.12.003

Larsen PB, Cancel J, Rounds M, Ochoa V (2007) Arabidopsis ALS1 encodes a root tip and stele localized half type $A B C$ transporter required for root growth in an aluminum toxic environment. Planta 225(6):1447-1458 doi:10.1007/s00425-006-0452-4

Larsen PB, Geisler MJB, Jones CA, Williams KM, Cancel JD (2005) ALS3 encodes a phloem-localized $A B C$ transporter-like protein that is required for aluminum resistance in Arabidopsis. Plant J 41(3):353-363. doi:10.1111/j.1365-313X.2004. 02306. $\mathrm{x}$

Ligaba A, Katsuhara M, Ryan PR, Shibasaka M, Matsumoto H (2006) The BNALMT1 and BnALMT2 genes from rape encode aluminum-activated malate transporters that enhance the aluminum resistance of plant cells. Plant Physiol 142(3):1294-1303. doi:10.1104/pp.106.085233 
Liu MY, Chen WW, Xu JM, Fan W, Yang JL, Zheng SJ (2013) The role of VUMATE1 expression in aluminium-inducible citrate secretion in rice bean (Vigna umbellata) roots. J Exp Bot 64(7):1795-1804. doi:10.1093/Jxb/ Ert039

Ma JF (2000) Role of organic acids in detoxification of aluminum in higher plants. Plant Cell Physiol 41(4):383-390. doi:10.1093/pcp/41.4.383

Ma JF, Furukawa J (2003) Recent progress in the research of external Al detoxification in higher plants: a minireview. J Inorg Biochem 97(1):46-51. doi:10.1016/S0162-0134(03)00245-9

Ma JF, Nagao S, Huang CF, Nishimura M (2005) Isolation and characterization of a rice mutant hypersensitive to Al. Plant Cell Physiol 46(7):1054-1061. doi:10.1093/pcp/pci116

Ma JF, Ryan PR, Delhaize E (2001) Aluminium resistance in plants and the complexing role of organic acids. Trends Plant Sci 6(6):273-278. doi:10.1016/S1360-1385(01)01961-6

Ma JF, Shen R, Zhao Z, Wissuwa M, Takeuchi Y, Ebitani T, Yano M (2002) Response of rice to Al stress and identification of quantitative trait Loci for Al resistance. Plant Cell Physiol 43(6):652-659. doi:10.1093/pcp/pcf081

Ma JF, Zheng SJ, Matsumoto H, Hiradate S (1997) Detoxifying aluminium with buckwheat. Nature 390(6660):569-570. doi:10.1038/37518

Magalhaes JV, Liu J, Guimaraes CT et al (2007) A gene in the multidrug and toxic compound extrusion (MATE) family confers aluminum resistance in sorghum. Nat Genet 39(9):1156-1161. doi:10.1038/ng2074

McCouch SR, Teytelman L, Xu YB, Lobos KB, Clare K, Walton M, Fu BY, Maghirang R, Li ZK, Xing YZ, Zhang QF, Kono I, Yano M, Fjellstrom R, DeClerck G, Schneider D, Cartinhour S, Ware D, Stein L (2002) Development and mapping of 2240 new SSR markers for rice (Oryza sativa L.). DNA Res 9(6): 199-207. doi:10.1093/dnares/9.6.199

Miyasaka SC, Buta JG, Howell RK, Foy CD (1991) Mechanism of aluminum resistance in snapbeans : root exudation of citric acid. Plant Physiol 96(3): 737-743. doi:10.1104/pp.96.3.737

Nguyen BD, Brar DS, Bui BC, Nguyen TV, Pham LN, Nguyen HT (2003) Identification and mapping of the QTL for aluminum resistance introgressed from the new source, ORYZA RUFIPOGON Griff., into indica rice (Oryza sativa L.). Theor Appl Genet 106(4):583-593. doi:10.1007/s00122-002-1072-4

Nguyen VT, Burow MD, Nguyen HT, Le BT, Le TD, Paterson AH (2001) Molecular mapping of genes conferring aluminum resistance in rice (Oryza sativa L.). Theor Appl Genet 102(6-7):1002-1010. doi:10.1007/s001220000472

Nguyen VT, Nguyen BD, Sarkarung S, Martinez C, Paterson AH, Nguyen HT (2002) Mapping of genes controlling aluminum resistance in rice: comparison of different genetic backgrounds. Mol Genet Genomics 267(6):772-780. doi:10.1007/s00438-002-0686-1

Pellet DM, Grunes DL, Kochian LV (1995) Organic-acid exudation as an aluminum-resistance mechanism in maize (Zea mays L.). Planta 196(4): 788-795. doi:10.1007/Bf01106775

Rangel AF, Rao IM, Horst WJ (2009) Intracellular distribution and binding state of aluminum in root apices of two common bean (Phaseolus vulgaris) genotypes in relation to Al toxicity. Physiol Plantarum 135(2):162-173. doi:10.1111/j.1399-3054.2008.01183.x

Ryan P, Delhaize E, Jones D (2001) Function and mechanism of organic anion exudation from plant roots. Annu Rev Plant Phys 52:527-560. doi:10.1146/annurev.arplant.52.1.527

Ryan PR, Ditomaso JM, Kochian LV (1993) Aluminum toxicity in roots - an investigation of spatial sensitivity and the role of the root cap. J Exp Bot 44(259):437-446. doi:10.1093/Jxb/44.2.437

Sasaki T, Yamamoto Y, Ezaki B, Katsuhara M, Ahn SJ, Ryan PR, Delhaize E, Matsumoto $H$ (2004) A wheat gene encoding an aluminum-activated malate transporter. Plant J 37(5):645-653. doi:10.1111/j.1365-313X.2003. 01991.x

Sivaguru M, Baluska F, Volkmann D, Felle HH, Horst WJ (1999) Impacts of aluminum on the cytoskeleton of the maize root apex. Short-term effects on the distal part of the transition zone. Plant Physiol 119(3):1073-1082. doi:10.1104/pp.119.3.1073

von Uexkull HR, Mutert E (1995) Global extent, development and economicimpact of acid soils. Plant Soil 171(1):1-15

Wu P, Liao CY, Hu B, Yi KK, Jin WZ, Ni JJ, He C (2000) QTLs and epistasis for aluminum resistance in rice (Oryza sativa L.) at different seedling stages. Theor Appl Genet 100(8):1295-1303. doi:10.1007/s001220051438

Xia J, Yamaji N, Kasai T, Ma JF (2010) Plasma membrane-localized transporter for aluminum in rice. Proc Natl Acad Sci U S A 107(43):18381-18385. doi:10.1073/pnas.1004949107
Xia J, Yamaji N, Ma JF (2013) A plasma membrane-localized small peptide is involved in rice aluminum resistance. Plant J 76(2):345-355. doi:10.1111/tpj. 12296

Xue Y, Jiang L, Su N, Wang JK, Deng P, Ma JF, Zhai HQ, Wan JM (2007) The genetic basic and fine-mapping of a stable quantitative-trait loci for aluminium resistance in rice. Planta 227(1):255-262. doi:10.1007/s00425-0070613-0

Yamaji N, Huang CF, Nagao S, Yano M, Sato Y, Nagamura Y, Ma JF (2009) A zinc finger transcription factor ART1 regulates multiple genes implicated in aluminum resistance in rice. Plant Cell 21(10):3339-3349. doi:10.1105/tpc.109.070771

Yang JL, Li YY, Zhang YJ, Zhang SS, Wu YR, Wu P, Zheng SJ (2008) Cell wall polysaccharides are specifically involved in the exclusion of aluminum from the rice root apex. Plant Physiol 146(2):602-611. doi:10.1104/pp.107.111989

Yang JL, Zhang L, Li YY, You JF, Wu P, Zheng SJ (2006) Citrate transporters play a critical role in aluminium-stimulated citrate efflux in rice bean (Vigna umbellata) roots. Ann Bot-London 97(4):579-584. doi:10.1093/Aob/Mc1005

Yang JL, Zheng SJ, He YF, Matsumoto H (2005) Aluminium resistance requires resistance to acid stress: a case study with spinach that exudes oxalate rapidly when exposed to Al stress. J Exp Bot 56(414):1197-1203. doi:10.1093/Jxb/Eri113

Yang JL, Zhu XF, Peng YX, Zheng C, Ming F, Zheng SJ (2011) Aluminum regulates oxalate secretion and plasma membrane $\mathrm{H}+$-ATPase activity independently in tomato roots. Planta 234(2):281-291. doi:10.1007/s00425011-1402-3

Yang ZM, Sivaguru M, Horst WJ, Matsumoto H (2000) Aluminium resistance is achieved by exudation of citric acid from roots of soybean (Glycine max). Physiol Plantarum 110(1):72-77. doi:10.1034/j.1399-3054.2000.110110.x

Yokosho K, Yamaji N, Ma JF (2011) An Al-inducible MATE gene is involved in external detoxification of Al in rice. Plant J 68(6):1061-1069. doi:10.1111/j. 1365-313X.2011.04757.x

Zheng SJ, Ma JF, Matsumoto H (1998) High aluminum resistance in buckwheat I. Al-induced specific secretion of oxalic acid from root tips. Plant Physiol 117(3):745-751. doi:10.1104/pp.117.3.745

Zhu XF, Shi YZ, Lei GJ, Fry SC, Zhang BC, Zhou YH, Braam J, Jiang T, Xu XY, Mao CZ, Pan YJ, Yang JL, Wu P, Zheng SJ (2012) XTH31, encoding an in vitro XEH/ XET-active enzyme, regulates aluminum sensitivity by modulating in vivo XET action, cell wall xyloglucan content, and aluminum binding capacity in Arabidopsis. Plant Cell 24 (11):4731-4747. doi:10.1105/tpc.112.106039

\section{Submit your manuscript to a SpringerOpen ${ }^{\circ}$ journal and benefit from:}

- Convenient online submission

- Rigorous peer review

- Immediate publication on acceptance

- Open access: articles freely available online

- High visibility within the field

- Retaining the copyright to your article

Submit your next manuscript at $>$ springeropen.com 